Idaliana Kaczor (Łódź)

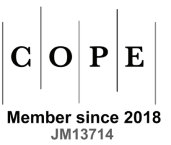

\title{
Characteristics of Roman Female Deities
}

In the reconstruction and analysis of the competences of Roman female deities, scholars are forced to base their research on existent literary sources, mainly Latin inscriptions, as well as prose and poetry. Due to the fact that Romans did not leave any sort of writings of theological nature, the surviving Latin literature becomes an essential source of information on this matter for researchers of Roman religious cults.

The fundamental source of inscriptions used in the reconstruction of the Roman religious system, including the characteristics of their gods, are carved stone tablets featuring the fasti, i.e. lists of sacral events organized in ancient Rome and subordinate cities ${ }^{1}$.

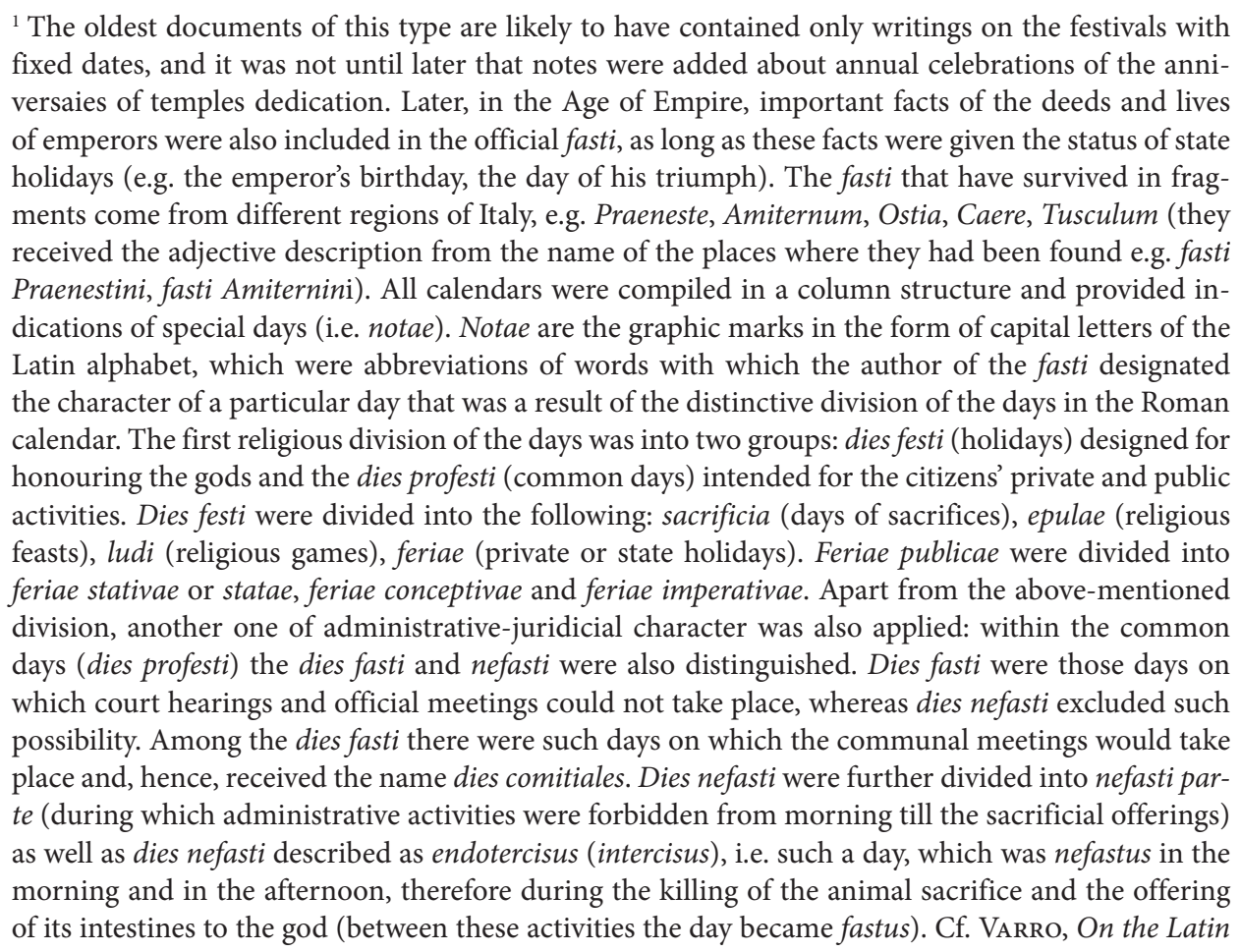


Although preserved in fragments, these records provide us with information to which gods sacral festivals were dedicated, and sometimes what sacral celebrations involved. Furthermore, knowing the timing of a holiday in the Roman religious calendar, we are able to reconstruct the character of the festival, and through this the competences of the honoured god ${ }^{2}$.

The purpose of the religious event recorded in the fasti usually resulted from its placement at a specific moment of the religious year, which was of great significance to the sacral community. The arrangement of the religious festivals in the fasti points to such a time in the Roman religious year, during which it was believed that divine power emanated the most and the fullest, i.e. to a degree that was required and necessary for fulfilling the material and non-material needs of the sacral community ${ }^{3}$. According to homo religious, such time was perceived as the most important and most effective for the interaction of the numen ${ }^{4}$ with men, an indispensable cooperation of practices that sustained and enlarged pax deorum, which was of great importance to the civilian and religious community ${ }^{5}$.

Language, VI, 31, vol. I, Books V-VII, vol. II, Books VIII-X, Fragments, trans. R.G. KenT, London 1938 [= LCL, 333-334] (cetera: VArro, De Lingua Latina); Ambrosii Theodosii Macrobii Saturnalia, I, 16, vol. I, ed. I. WILlis, Lipsiae 1963 [= BSGR] (cetera: MAcrobIUs, Saturnalia). Notae dierum were the following: dies fastus - F; dies comitialis - C; dies nefastus - N (or N and at the top a small F); dies endotercisus - EN (or E); the ligatue of the letters $\mathrm{N}$ and $\mathrm{P}$ is explained differently or as nefastus parte or as feriae publicae. Besides these abbreviations, the calendar also noted the abbreviated names of the three typical Roman fasti days: calendae (K), nonae (NON), ides (EID). All calendars contained usually three letter abbreviations of the names of the public holidays, e.g. LEM for Lemuria. For the discussion and listing as well as the graphic presentation of the fasti, see: CIL I ${ }^{2}$, Berlin 1903 and A. Degrassi, Fasti anni Numani et Iuliani, Rome 1963 [= IIt, 13.2].

${ }^{2}$ Cf. S.A. TAKács, Vestal Virgins, Sibyls and Matrons. Women in Roman Religion, Austin-Chesham 2008, p. 25.

${ }^{3}$ Servii Grammatici qui feruntur in Vergilii Carmina Commentarii, ed. G. Thilo, H. Hagen, vol. I, Aeneidos librorum I-V Commentarii, II, 141, ed. G. ThILo, Hildesheim 1961 (cetera: Servius, In Vergilii Aeneidos): Nam ea numina invocans, quae sunt conscia numina veritatis, quia et pontifices dicunt, singulis actibus proprios deos praeesse. Hos Varro certos deos appellat. Cf. ARnobius, Adversus nationes; L. Annaei Senecae Ad Lucilium Epistulae Morales, 41, vol. I-II, ed. L.D. Reynolds, Oxonii 1965 [= SCBO] (cetera: SENECA, Epistulae Morales ad Lucilium): Si tibi occurrerit vetustis arboribus et solitam altitudinem egressis frequens lucus et conspectum caeli $<$ densitate $>$ ramorum aliorum alios protegentium summovens, illa proceritas silvae et secretum loci et admiratio umbrae in aperto tam densae atque continuae fidem tibi numinis faciet; SENECA, Epistulae Morales ad Lucilium, 95: Primus est deorum cultus deos credere; deinde reddere illis maiestatem suam, reddere bonitatem sine qua nulla maiestas est; scire illos esse qui praesident mundo, qui universa vi sua temperant, qui humani generis tutelam gerunt interdum incuriosi singulorum. Hi nec dant malum nec habent; ceterum castigant quosdam et coercent et inrogant poenas et aliquando specie boni puniunt.

${ }^{4}$ The term numen used by the Romans has no equivalent in other ancient European religions. It denotes the non-figurative, non-nominative and explicit divine intervention into human life. It is possible that the Romans coined the term numen before the anthropomorphisation of the deities of their pantheon. Numen, therefore, would be a deus only without the human figure.

${ }^{5}$ The 'peace with the gods', which was established and constantly renewed not only during the festivals but also in quotidian activities that the Romans assigned sacral value. The pax deorum 
The Romans' pragmatic attitude to their reality created a model of the civil-religious community based on the co-responsibility of its members in maintaining the group's continuity and permanence; every Roman man and woman fulfilled a set of life duties that were meant to secure the existence of the group, whereas the state required from its civilians such behaviour that secured the existence of the community ${ }^{6}$.

Moreover, the Romans' foresight constructed such a way of guaranteeing the effectiveness of the above-mentioned actions undertaken by the Roman society by placing the co-responsibility for the fate of Rome and its inhabitants onto their deities, too ${ }^{7}$. This divine guardianship has been integrated with civil responsibilities fulfilled by the Romans, whereas specific duties have been submitted under the patronage of specific gods ${ }^{8}$. Such simple combination of human and divine purposes formed the Roman citizens into a pious people, obedient to their gods,

ensured the continual existence of Rome. Cf. Cicero, De Legibus, I, 34, [in:] Cicero, De Re Publica. De Legibus, trans. C.W. Keyes, London 1969 [= LCL, 213]: etiam in deos caerimoniae religionesque toll $<e>n t u r$, quas non metu, sed ea coniunctione quae est homini cum deo conseruandas puto. Cf. A. Gillmeister, D. Musia£, W cieniu Kapitolu. Religia starożytnych Rzymian, Kraków 2012 , p. 32.

${ }^{6}$ Cicero, De Re Publica, I, 39, [in:] Cicero, De Re Publica... (cetera: Cicero, De Re Publica).

${ }^{7}$ Cicero, De Re Publica, VI, 13.

${ }^{8}$ The Latin indigitamentum (pl. indigitamenta) is a derivative of the verb indigitare - to call, to call on a god, to ritually summon the gods' and regards the religious practices of the pontifices (Nonii Marcelli De conpendiosa doctrina libros XX, vol. I, LL. I-III, ed. W.M. LindsaY, Lipsiae 1903, p. 559; Macrobius, Saturnalia, I, 12, 21). A single indigitamentum, which epithet usually came from the verb referring to a specific activity, was believed to accompany a Roman in his/her actions, i.e. in the realization of his/her life activity that simultaneously was perceived as a display of the activity of the indigitamentum itself. To a Roman, the activity of an indigitamentum expressed its power and will to participate and actualise the actions taken by man. Therefore, it seems that, in the view of the Roman sacral community, the idea of indigitamentum was similar to that of numen, however, in contrast to the latter, which needn't always to be defined by a name, the former did possess such a name. Cf. M. Terentius Varro, Antiquitates Rerum Divinarum, vol. I, Die Fragmente, fr. 87, ed. B. Cardauns, Wiesbaden 1976 (cetera: Varro, Antiquitates rerum divinarum); Servius, In Vergilii Aeneidos, II 141. In Antiquitates Rerum Divinarum, VArro (fr. 90-202) lists ca. 100 names and competences of this category of divine beings. According to many scholars, such divinization of everyday human activities is typical for the Roman religion (J. Ries, Héritage indo-européen et religion romaine. À propos de La religion romaine archaïque de Georges Dumézil, RTL 7, 1976, p. 485). Usually the cognomina of the Roman gods reflect one of their many competences and illustrate his/ her patronage over a specific activity. This is a well-known process in the evolution of Roman beliefs of transforming individual functions ascribed earlier to the indigitamenta into one of a god's sacral competences. For instance, VArro (Antiquitates Rerum Divinarum, fr. 100, 101) gives the example of an indigitamentum of the name Lucina, a derivative of the Latin verb lucerre 'to shine', which in time became the cognomen of the goddess Juno as the patroness of women who were pregnant, in labour and their new-born children.

${ }^{9}$ Cicero, De Haruspicum Responsis, 19, [in:] Cicero, The Speeches, trans. N.H. WATts, London 1961 [= LCL, 158] (cetera: CiCERo, De Haruspicum Responsis). 
constituting a civilian as well as religious group ${ }^{10}$ responsible, in both individual and collective sense, for the future of the community and Rome itself.

The Roman sacral system comprises of many holidays dedicated to goddesses, as well as of few clearly prominent sequences of festivals that focus on the primary religious idea, in which the main numinous figure is a female deity ${ }^{11}$. Observations emerging from the analysis of the fasti, which are a valuable and essential source in the research on the competences of Roman goddesses and the character of their festivals, broadened by the information provided by literature and enriched by archaeological and linguistic studies, allow a scholar of religion to answer the following questions: 1) which Roman civil and religious duties did the female numina patronize; 2 ) in which way did these deities make it possible for the city inhabitants to fulfil their tasks given to them by their own community; 3 ) how, when and why did the actions of the Roman citizens accept religious value that augmented the sphere of sacrum?

Based on the records of the Roman holidays found in the sacral calendar-based lists, we can easily distinguish those dedicated to female deities. The chronologically written fasti render the image of a cohesive and universal religious system established by the citizens of Rome, which is clearly reflected in the nature of the holidays. The placement of the event at an important moment of the sacral year defined the character and competences of the goddess, in whose honour the festival was held ${ }^{12}$.

\footnotetext{
${ }^{10}$ The Romans formed a civil-religious community. Cf. J. ScHeID, Le délit religieux dans la Rome tardo-républicaine, PEFR 48, 1981, p. 168: toute la théologie gravitait autour de salut public; IDEM, La religion des Romains, Paris 1998 [= C.HA], p. 110: Il est vrai que dans le monde romain il n'existait pas de différence entre la vie 'lä̈que' et la vie religieuse. Tout acte public était religieux et tout acte religieux était public; IDEM, La religione a Roma, trans. M.N. PIERINI, Bari 1983, p. 8: La religione romana [...] può essere caratterizzata da due elementi: è una religione sociale ed è religione fatta di atti di culto. Religione sociale, essa è praticata dall'uomo in quanto membro di una communità e non in quanto singolo individuo, persona.

${ }^{11}$ Cf. the Roman agrarian festivals: Rome was an agricultural society, which its cultic cycle reinforced. Like the seasons, there was great religious activity in preparation for a during the growing season, while there was little of note after the harvest season, S.A. TAKÁcs, Vestal..., p. 25.

${ }^{12}$ Fasti are a list of holidays indicated in particular months of the year. A research problem, with which this article deals with, requires keeping the chronological structure in the presentation of the characteristics of the Roman female deities. The first information presents the day of the month, the next the name of the worshipped goddess, the last is the name of the festival held in her honour. Occasionally, the cognomen is placed after the goddess' name, under which on this day she was honoured.
} 


\title{
Roman female deities and their festivals ${ }^{13}$ - feriae stativae or statae sollemnes ${ }^{14}$
}

\author{
Mensis Ianuarius \\ 11 and 15 January: Carmenta vel Carmentes ${ }^{15}$; Carmentalia vel Karmentalia. \\ 16 January: Concordia ${ }^{16}$; Concordiae Augustae [eo die] aedis dedicata est ${ }^{17}$.
}

Carmenta was the goddess of pregnancy and childbirth. She was responsible for the foetus' position in the mother's womb ${ }^{18}$. Literary sources mention two Carmentas - Porrima (or Prorsa) and Postverta. The former was the patron of a birth of a child born with its head first (i.e. head childbirth), the latter of a birth when the child came feet first (i.e. pelvis childbirth) ${ }^{19}$, which was very dangerous and often ended in the death of both mother and child. During the Carmentalia, the whole Roman community gathered in the deity's temple, in which it was forbidden to wear leather or other skins of dead animals, a ban that emphasizes the goddess' relation with her being a patroness of life.

\author{
Mensis Martius \\ 1 March: Iuno Lucina; Matronalia. \\ 5 March: Isis; Isidis navigium ${ }^{20}$.
}

\begin{abstract}
${ }^{13}$ The list of these festivals has been based on the data found in: CIL I $\mathrm{I}^{2}$, p. 306-338.
${ }^{14}$ These were public holidays, listed in the fasti, that were held annually on a fixed or stable date of the calendar (VArro, De lingua Latina, VI, 28).

${ }^{15}$ Carmentes is the plural form of the goddess' name.

${ }^{16}$ In colloquial Latin, the term concordia means 'agreement'. The Concordia found in the fasti refers to the deified virtue, whereas the following description of the celebration contains information about the consecration of the deity's temple, which anniversary was celebrated. Concordia had in Rome one more temple, which consecration was annually celebrated on 5 February (CIL I ${ }^{2}$, p. 309). Her festival is mentioned also as being held on 22 July $\left(C I L \mathrm{I}^{2}\right.$, p. 323). The fasti list also the anniversaries of the dedication of temples for other deified virtues under the following dates: 29 May and 2 August (Virtus - Courage), 3 June (Bellona - War), 8 June (Mens - Mind), 1 July and 12 August (Felicitas - Happiness) and 9 October (Fausta Felicitas - Favoring Good Luck), 4 July and 30 January (Pax - Peace), 1 August (Spes - Hope), 5 August (Salus - Success), 28 August (Victoria - Victory), 1 October (Fides - Fidelity), 15 December (Fortuna - Fate). Most deities of such type had no other holidays nor did they have an expanded cult. The festivals in their honour where limited to celebrating the anniversary of the consecration of temples, for this reason these festivals are not discussed in this article.

${ }^{17}$ This information is often found in the notes of the fasti authors and denotes that on this particular day the god's temple was consecrated; it was the only celebration accompanying this holiday.

${ }^{18}$ The Carmentalia were the first in the year festival that was celebrated by women under the auspices of those female deities that cared for pregnant women and, through this, the number of the Roman community. The fact that this festival was placed at the beginning of the year reflects how important the physical state of their citizens was to the Romans. Cf. S.A. TAKács, Vestal..., p. 28: The Carmentalia was the first festival of the 12-month year that involved woman.

${ }^{19}$ Auli Gellii Noctium Atticarum libri XX, XVI, 16, 4, vol. I-II, rec. C. HosIUs, Stutgardiae 1981 [= BSGR].

${ }^{20}$ Isis was an Egyptian goddess, whose cult was known in Rome already in the first century BC, but spread only during the empire after the Julio-Claudian era (M. JACZYNowsKA, Religie świata
\end{abstract}


15 March: Anna Perenna; feriae Annae Perennae

19 March: Minerva; Quinquatrus Maiores vel Quinquatria. [...] Minervae aedis

[...] eo dies est dedicata ${ }^{21}$.

31 March: Luna ${ }^{22}$. Lunae eo die aedis dedicata est.

$J_{u n o}^{23}$ was the protectress of young Roman women, especially those who were married. She took care of pregnant women, women in childbirth, women in confinement and also of newborn babies. As Iuno with the epithet Lucina, she received new-borns into the world and bestowed upon them light, the symbol of life. At the Matronalia, Roman women went to her temple, where they prayed for safe childbirth for themselves and their children.

In the Roman pantheon, Anna Perenna ${ }^{24}$ deified the new year that began in March. Her approval was supposed to guarantee the continuity of the surrounding world and maintenance of life until the next celebrations held in her honour ${ }^{25}$. The Romans celebrated the festivity of Anna Perenna outside the city, on the shores of the river Tiber, where crowds of pairs of lovers gathered for feasting and play. Such unusual course of the sacrum Annae Perennae resulted from the timing of this festivity in the Roman sacral calendar, since March 15 was the first full moon in the new sacral year of the Roman society ${ }^{26}$.

To the Romans, Minerva was mostly perceived as the divine patroness of various crafts and professions as well as the people following them ${ }^{27}$. City inhabitants ascribed to her those competences of the Greek goddess Athena of the epithet Ergane; this may indicate the non-Roman provenance of her cult. Both celebrations

rzymskiego, Warszawa 1987, p. 204). Celebrations in her honour took place between 28 October and 4 November (CIL I' ${ }^{2}$ p. 333-334).

${ }^{21}$ Minerva, a goddess of non-Roman origin, was honoured as the patroness of various crafts and professions as well as of craftsmen. Cf. D. SABbatucCI, La religione di Roma antica. Dal calendario festivo all'ordine cosmico, Milano 1988, p. 110-111; S.A. TAKács, Vestal..., p. 48.

${ }^{22}$ Latin luna 'moon'. It is likely that on this day the temple was dedicated to the goddess. The fasti mention another enigmatic festival in honour of the goddess to be held on 24 August (CIL I' 2 p. 327) and 28 August $\left(C I L \mathrm{I}^{2}\right.$, p. 327). On this day, the temples for Luna and the god of the Sun (Sol) were erected. In the Roman belief system, the worship of heavenly bodies as deities was not strongly emphasized.

${ }^{23}$ The theonym Iūno contains the Indo-European root *iūn-, which also appears in later Latin words, such as iūnix 'heifer', iūnior 'subst. young woman' (A. CARnoy, Dictionnaire étymologique de la mythologie gréco-romaine, Louvain 1957, p. 86; A. WALDE, J.B. HofmANn, Lateinisches etymologisches Wörterbuch, vol. I, Heidelberg 1938 [= IgB, 1], p. 731).

${ }^{24}$ Latin annus 'year'; perennis 'lasting a year, yearly'. This celebration belongs to those festivals at the turn of the sacral year. Often, such festivals comprised of a ritual scenario that was untypical for them (I. Kaczor, Sakralizacja czasu w rzymskim systemie wierzeń, [in:] Kategorie i funkcje czasu w ujęciu starożytnych, ed. J. Czerwińska, I. Kaczor, M. KoźLuk, A. Lenartowicz, J. Rybowska, Łódź 2009, p. 230).

${ }^{25}$ Macrobius, Saturnalia, I, 12, 6.

${ }^{26} \mathrm{~S}$. Benoist, La Fête à Rome au premier siècle de l'Empire. Recherches sur l'univers festif sous les règnes d'Auguste et des Julio-Claudiens, Bruxelles 1999, p. 150.

${ }^{27}$ Ovid's Fasti, III, 817-831, trans. J.G. Frazer, London 1959 [= LCL, 253] (cetera: Ovidius, Fasti). 


\title{
dedicated to Minerva - Quinquatrus Maiores ${ }^{28}$ and Quinquatrus Minusculae - were holidays of professional artisans'.
}

\author{
Mensis Aprilis \\ 1April: Fortuna Virilis; sacrum Fortunae Virili ${ }^{29}$. \\ 1April: Venus Verticordia; Veneralia. \\ 4-10 April: mater deum Idaea; ludi Megalesiaci ${ }^{30}$. \\ 5 April: Fortuna Publica; Fortunae Publicae eo die aedis dedicata est. \\ 15 April: Tellus; Fordicidia vel Hordicidia. \\ 19 April: Ceres; Cerialia, ludi Ceriales (12-19 April) ${ }^{31}$. \\ 21 April: Pales; Parilia. \\ 23 April: Venus Erycina vel Erucina; Veneri Erycinae eo die aedes dedicata est ${ }^{32}$. \\ 25 April: Robigo; Robigalia. \\ 28 April - 3 May: Flora; Floralia ${ }^{33}$.
}

Fortuna $^{34}$ was the deity of all incidents, be it good or bad, that happened in people's lives. In Rome, the goddess was worshipped under may epithets, which shows that she was perceived as the patroness of important events in the quotidian actions of men and society ${ }^{35}$. During the sacrum Fortunae Virili, women

\footnotetext{
${ }^{28}$ One of the authors of the fasti (CIL I ${ }^{2}$, p. 329) called this holiday artificum dies, 'day of the artists', who, in the view of ancient Romans, were people of artistic and technical professions.

${ }^{29}$ Latin virilis 'male'; subst. virile 'male genital'.

${ }^{30}$ Mater deum or magna Mater is the Phrygian goddess Cybele. Her cult was introduced in Rome in the 3 century BC. On 10 April, her temple was dedicated (CIL I' ${ }^{2}$ p. 315). The Romans included the celebrations held in her honour, which had already begun by the end of March, into the socalled sacra peregrina, i.e. the worshipping of foreign gods that have been officially accepted into the Roman pantheon (Festus, De verborum significatu, [in:] Glossaria Latina, vol. IV, Placidus, Festus, ed. J.W. Pirie, W.-M. Lindsay, Hildesheim 1965 (cetera: Festus, De verborum significatu), p. 342.

${ }^{31} \mathrm{Ludi}$ were a few day celebration added to the primary festival held in honour of the god.

${ }^{32}$ In Rome, the assigning value to the cult of Venus was basically for political purposes, because the Romans, in creating the legendary beginnings of their city, exploited the well-known from Greek literature story about the Trojan war, from which Aeneas was supposed to escape, reach Italy, and then found the dynasty of Roman kings. His mother, Aphrodite, was identified with Venus, the Roman goddess of the same competences. In Rome there appeared the cult of Aphrodite worshipped on the Aventine hill. This was dedicated to her on 23 April, earlier on 19 August. In the Julio-Claudian era and in later times, the Roman emperors often referred to the patronage of Venus over the imperial family that ruled the Imperium Romanum. At that time, Venus became an official state deity, whose new gained functions were reflected in the epithets Victrix vel Victoria and Genetrix.

${ }^{33}$ Floralia was the last spring agricultural festival held on a fixed date, noted by the Roman sacral-calendar, the fasti. At the end of May, the body of priests, fratres Arvales, performed in the goddess' orchard the sacrum Deae Diae, the annually proclaimed and complex purification ritual, which marked the end of the sowing of seeds and the growing of crops and initiated the time of harvest anticipation. The course of the holiday is reconstructed on the basis of the priests' notes and the inscriptions (Acta Fratrum Arvalium quae supersunt, ed. W. Henzen, Berolini 1874).

${ }^{34}$ Literally: 'fate'.

${ }^{35}$ Cf. festivals held on: 25 May (Fortuna Publica Populi Romani), 24 June (Fors Fortuna), 6 July (Fortuna Muliebris), 30 July (Fortuna huiusque diei), 13 November (Fortuna Primigenia).
} 
took a ritual bath in those public bathhouses, where men earlier have bathed, and prayed to the goddess to hide their beauty flaws from the eyes of their lovers.

The ancient Romans considered Venus ${ }^{36}$ to be one of the vegetative divinities that took care of garden plants. In time, when the city inhabitants started to identify this goddess with Aphrodite, i.e. the mother of their ancestor Aeneas, they extended her sacral functions as they started to recognize in her a deity responsible for human feelings and physical love. Venus Verticordia who directed the heart in one's direction, bestowing love celebrated her holiday the Veneralia on 1 April. During the Veneralia, both married and unmarried Roman women took a ritual bath. The course of the ritual, as it is described by Ovid in the Fasti ${ }^{37}$, points to its Greek origin.

According to the religious mentality of the Romans, Tellus was the deity of earth's fertility, perceived as the land, the cultivated soil that received seeds and bore fruit ${ }^{38}$. Two important Roman festivals were dedicated to this goddess, which clearly reflected her divine competences in twofold manner: 1) by the timing of the festival itself, and 2) by the laying emphasis in the rituals on the primary function of Tellus. During the Fordicidia, which took place in mid-April, over two months after sowing the seeds ${ }^{39}$, the Romans prayed to the goddess for good harvest. An in-calf heifer was sacrificed to her, on the basis of the belief that Telluri plenae victima plena datur ${ }^{40}$, i.e. Tellus fertilized with seeds receives a pregnant cow in order to ensure good harvest for the city inhabitants. The Fordicidia are the first agricultural-vegetative festival that has been placed in the sacral calendar on a fixed date.

Several days after the Fordicidia, the Romans honoured Ceres, who, according to early Roman belief, was responsible for the growth of cereals from sowed grain ${ }^{41}$

\footnotetext{
${ }^{36}$ The lexeme venus derives from the Indo-European root *Áen- 'to desire, to want'. The Latin venus in the common meaning refers to 'bodily love', however, from the moment it became the name of the goddess, it denotes the force of sexual desire (R. Schilling, La relation Venus-Venia, L 21, 1962, p. 4). Cf. IDEM, La religion romaine de Vénus depuis les origines jusqu'au temps d'Auguste, Paris 1954, p. 60. ${ }^{37}$ Ovidius, Fasti, IV, 133-144; 151-160. Researchers underline the significance of this work for religious studies. Cf. J. RüPKe, Roman Religion-Religions of Rome, [in:] A Companion to Roman Religion, ed. IDEM, Malden 2007 [= BCAW], p. 8.

${ }^{38}$ Columella, On Agriculture, X, 1, 157, vol. III, Books 10-12. On Trees, trans. E.S. Forster, E.H. HeFFner, London 1955 [= LCL, 408].

${ }^{39}$ The ceremonious sowing termed feriae Sementivae were a festival of a non-fixed date and took place at the end of January; these were held in the honour of two goddesses, Tellus and Ceres. The description of the festival is found in OviD's Fasti (I, 657-696).

${ }^{40}$ Ovidius, Fasti, IV, 635.

${ }^{41}$ Ceres' primary competences may be recognized in her name. The theonym Ceres contains of the Indo-European root $*$ jer-, $*$ jere- ' to grow, to cause growth'. The same root appears in the Latin verb creare 'to create, to bring to life' (A. WALDE, J.B. Hofmann, Lateinisches..., vol. I, p. 204; A. CARNOY, Dictionnaire..., p. 37) and crescěre 'to grow, germinate, be born' (G. RADKE, Beobachtungen zum Namen des Festes der Cerialia, [in:] Hommages à Henri Le Bonniec. Res Sacrae, ed. D. PorTe, J.-P. Néraudau, Bruxelles 1988 [= ColL, 201], p. 370; B.S. Spaeth, The Roman Goddess Ceres, Austin 1996, p. 33).
} 
that had been offered to Tellus. During the Ceralia, Ceres received the offering of a covered sow. Without any doubt the magical symbolism of a pregnant sacrifice to both Tellus and Ceres is identical, since both goddesses were co-responsible for the fertility of cereals and other plants: the former by accepting seeds sowed by farmers, the latter by bestowing these with the force of germination and growth that was visible to men.

In the Roman pantheon, the goddess Pales was the patroness of herds of farm animals that could graze on meadows from the day of her holiday, the Parilia; this day was considered were the beginning of the new shepherd year. During the festival, the animals and their shepherds participated in a purification ritual. Such rite performed at the Parilia was of apotropaic nature, for it aimed at protecting from danger the herd and herdsmen who were away from other peoples' dwellings. Also, Pales' protection was supposed to aid the fertility of animals. According to the Roman poet Tibullus ${ }^{42}$, young people were especially fond of this holiday, as on this day they were allowed to feast and play in nature.

The Romans considered Robigo ${ }^{43}$ to be a dangerous deity, due to the fact that in unfavourable climate conditions (high temperature and humidity) she could infect young plants with fungus. For this reason she was considered to be the deified symptom of this disease. The festival dedicated to her, Robigalia, had a supplicant, i.e. apotropaic character, as the rituals were meant to prevent the harmful activity of the numen. The sacral practices took place in an orchard dedicated to the goddess, where the priest sacrificed a sheep and a red-haired puppy, whose colouring was a reference to the red blight that attacked the crops.

Another vegetative Roman deity was Flora ${ }^{44}$, the deified force inspiring flowers to bloom on all plants, from the branches of fruit trees and other cultivated bushes as well as spikes of grain. Flora belonged to the group of gods whose potential wrath one was supposed to avoid and attempt to pacify her dissatisfaction beforehand ${ }^{45}$. During the festival in honour, which was augmented with the ludi, theatrical performances were shown, during which Roman courtesans were prepared and publicly presented; the prostitutes appeared then naked, showed a sexy dance and made jokes of explicit sexual nature ${ }^{46}$.

Mensis Maius

15 May: Maia; Mercurio Maiae eo die aedis dedicata est.

25 May: Fortuna Publica Populi Romani; Fortunae Publicae Populi Romani eo die aedis dedicata est.

\footnotetext{
${ }^{42}$ Albii Tibulli Aliorumque Carmina, Elegiae II, 5, 95-102, ed. G. Luck, Stutgardiae 1988 [= BSGR].

${ }^{43}$ Literally 'cereal rust'.

${ }^{44}$ The Latin flöra is connected with other Latin terms with the same meaning: flōs (flöris) 'flower in the state of blossoming and blooming' and flōrēre 'to bloom, blossom, grow lushly'.

${ }^{45}$ Cicero, The Verrine Orations, V 36, vol. I-II, trans. L.H.G. Greenwood, London 1959-1960 [= LCL, 221].

${ }^{46}$ Valeri Maximi Factorum et Dictorum Memorabilium libri novem, II, 10, 8, ed. C. HaLm, Lipsiae 1865.
} 
Maia was an old Roman deity that over time lost its religious significance and its primary competences became forgotten. She was later identified with the Greek goddess Maia, mother of Hermes, whose religious functions were identified with that of the Roman Mercury. Hence the shared temple for both divinities.

Mensis Iunius

1 June: Iuno Moneta; Iunoni Monetae eo die aedes dedicata est. 1 June: Carna; circenses fabricii (fabarici) vel ludi fabarici ${ }^{47}$.

9 June: Vesta; Vestalia.

11 June: Mater Matuta; Matralia.

13 June: Musae; Natalis Musarum ${ }^{48}$.

19 June: Minerva; Quinquatrus Minusculae ${ }^{49}$. Minervae eo die aedis dedicata est.

24 June: Fors Fortuna; sacrum Fortis Fortunae.

The name Carna itself may show the primary sacral competences of the deity. According to linguists, the goddess' theonym contains the root that appears also in the Latin term caro 'piece of meat' ${ }^{50}$, since Carna took care of the inner organs of men, whose good health was protected by her. The goddess was also responsible for the absorption of nutrients from consumed foods that supported the functioning of the human body ${ }^{51}$. Her dedicated offering was a mush of beans and flour as well as lard, that is the types of food that were commonly regarded as most nutritious $^{52}$. Ovid ${ }^{53}$ gives a description of a ritual that was supposed to heal a child who was close to dying after being attacked by a strix; the goddess herself protected and participated in this ritual. Such apotropaic rite corresponds to the sequence of rituals that were supposed to ensure the protection and health of the youngest members of the Roman society.

The Romans identified Vesta with the hearth as well as in temple fire. The fire that was a visible sign of the goddess' presence in her temple at the Forum Romanum was considered a symbol of Rome's permanence and stability of its fate $e^{54}$. The

\footnotetext{
${ }^{47}$ The name of this festival should be related to the Latin term faba 'bean'.

${ }^{48}$ The term natalis mentioned by the author of the fasti in the information about the festival means that on this day was the dedication of the goddess' temple occurred. The Muses were Greek divinities, the patronesses of art and science. The consecration of their temple coincided probably with the time of the festival of Minerva (19 June) the patroness of musicians (CIL I $\left.\mathrm{I}^{2}, \mathrm{p} .320\right)$.

${ }^{49}$ The information in the fasti is a supplementation to the note from 19 March. It is probable that in June the building of the goddess' new temple was formally declared and then finished in March, hence the two days of its dedication (CIL I $\mathrm{I}^{2}$, p. 320).

${ }^{50}$ G. Radke, Die Götter Altitaliens, Münster 1965, p. 84.

${ }^{51}$ G. DumÉZIL, Carna, REL 38, 1960, p. 90.

${ }^{52}$ Macrobius, Saturnalia, I, 12, 32-33.

${ }^{53}$ Ovidius, Fasti, VI, 155-168.

${ }^{54}$ An essential festival in honour of Vesta, albeit not included in the fasti, was the extinguishing and lighting of the new fire in her temple. This ritual took place on the first day of March, i.e. the first day of the new Roman religious year (MAcrobius, Saturnalia, I, 12, 6).
} 
Vestalia held in June were of mainly purifying character, during which garbage was swept out of the goddess' temple and was later thrown into the river Tiber. Moreover, the goddess was the patroness of bakers, what may be suggested by the fact that the Romans, in the archaic times of their religion, attributed Vesta the functions of a deity responsible for providing the citizens with food ${ }^{55}$.

It is difficult to reconstruct the primary sacral competences of the goddess Mater Matuta, since the single source for their interpretation is the mention of an enigmatic rite that accompanied the celebrations held in her honour. At the Matralia, women and their children held by their mothers' sisters, probably in order to stress both parental and sisterly bond gathered in the goddess' temple. Slave women were not allowed in the temple of Mater Matuta, and during the Matralia one slave was whipped and then driven out of the temple. It is possible that this ritual was meant to be purifying and apotropaic, whereas the slave woman played the role of a 'scapegoat'; by taking on the sins and faults of the sacral community, she liberated the group from the responsibility for them.

Fors Fortuna was one of the hypostasis of the deity of chance, i.e. events and incidents in one's life that were independent from human will. The significance of this goddess is emphasized by the timing of the festival held in her honour and the ritual conduct of its participants. Sacrum Fortis Fortunae occurred on the summer solstice, which was assigned the sacral value of the moment of the combat of two contradictory forces of nature: the benevolent light which symbolized life and the dangerous darkness which was, in accordance to the religious code of ancient communities, identified with death. This festival was held at the river Tiber, probably near the goddess' temple. The participants, who were usually young people, would come on foot or take boats decorated with flowers down the river; they would then organize common feasts.

Mensis Iulius

6 July: Fortuna Muliebris ${ }^{56}$; Fortunae Muliebri eo die aedis dedicata est.

\footnotetext{
${ }^{55}$ Cf. R. Wright, Vesta. A Study on the Origin of a Goddess and Her Cultus, Washington 1995, p. 196: the Vestal priestesses' exclusive association with the ritual preparation and sacramental use of grain seemed to be a consistent with the Great Goddess' sovereignty over the growth, storage and preparation of this staple. ${ }^{56}$ Goddess of female fertility. Such role of Fortuna Muliebris is questioned by Celia E. Schultz (Women's Religious Activity in the Roman Republic, Chapel Hill-London 2006 [= SHGR]). The scholar indicates the fact that the literary sources, on which the analysis of the role of women in Roman religion is based on, are non-objective since only men were their authors. Schultz discusses the role of women in Roman religion from a gender perspective (ibidem, p. 89-93). Similar observations have been already expressed earlier: The lesson from Roman religion was, as I showed, that women never had a ritual identity independent of their relationship to men. In one sense this is not peculiar to Rome. Women have always been classified according to their sexuality. Even today women are classified according to the stages of their sexual development into roughly pre-menarche, post-menarche and post-menopausal stages (A. STAPLES, From Good Goddess to Vestal Virgins. Sex and Category in Roman Religion, London 1998, p. 160).
} 
7 July: Iuno Caprotina ${ }^{57}$; ancillarum feriae vel Nonae Caprotinae ${ }^{58}$.

25 July: Furrina; Furrinalia.

30 July: Fortuna huiusque diei; Fortunae huiusque diei eo die aedes dedicata est.

The sacral competences of Juno clearly attribute her patronage over young girls and married women, and her divine functions are confirmed in the festivals held in her honour, the ritual conduct of her worshippers and the prayer phrases. Nonae Caprotinae gathered women from beyond the city, but slave women also participated in these celebrations, often taking on the responsibilities for the sacral offenses of the whole community in the purification rituals,. The offering of a sap resembling milk from a tree was used and made in Juno's honour under a wild fig tree ${ }^{59}$, after which slave women held a mock fight with rocks and whipped each other with fig tree twigg ${ }^{60}$. The ritual arrangement of this festival resembled rites of 'expelling evil forces', known in many archaic communities ${ }^{61}$. In this type of rituals, the people, who personified these powers, were expelled by being beaten with twigs and thrown at with rocks. Often, they carried fig fruit around their necks. Because the Nonae Caprotinae were dedicated to Juno and only women were allowed to participate in them, this apotropaic in its character festival could have aimed at averting dangers threatening married women expecting a child.

Like some other other female Roman deities (such as Feronia ${ }^{62}$ and Maia), Furrina gradually lost her sacral significance and became a goddess of unclear heritage and uncertain competences ${ }^{63}$. This was due to the fact that we are not able to reconstruct the primary functions of Furrina, because of the few and difficult in interpretation remarks found in Roman literature and the short note in the Fasti.

Mensis Augustus

12 August: Venus Victrix vel Victoria; Veneri Victrici vel Victoriae eo die aedis dedicata est. 13 August: Diana; Natalis Dianes ${ }^{64}$.

19 August: Venus; Veneri eo die aedis dedicata est.

23 August: Ops Opifera; Opi Opiferae eo die aedis dedicata est. 25 August: Ops Consiva; Opiconsivia vel Opeconsivia.

\footnotetext{
${ }^{57}$ The goddess' epithet is related to the Latin noun caper 'billy-goat' (capra 'goat'). In ancient culture, this animal was a theriomorphic symbol of fertility.

${ }^{58}$ VARRo names the festival in such manner (De lingua Latina, VI, 18).

${ }^{59}$ The Latin caprificus literally means 'goat fig'.

${ }^{60}$ Varro, De lingua Latina, VI, 18.

${ }^{61}$ J.G. Frazer, Złota gałaź, trans. H. KrzeczKowski, Warszawa 1996, p. 425-432.

${ }^{62}$ Confer: the anniversary of the dedication of Ferronia's temple (13 November), about which even less information is available.

${ }^{63}$ VArro, De lingua Latina, VII, 45.

${ }^{64}$ On this day, Diana's temple on the Aventine was dedicated, whereas the Romans took over her cult from the sanctuary not far from Aritia, where she was worshipped under the epithet of Nemorensis 'woodland like. During the nocturnal festival, women gathered in the goddess' grove asking Diana for successful childbirth.
} 
$\mathrm{Ops}^{65}$ is a female deity of wealth and opulence. The goddess' epithets: Opifera 'she, who bestows plenty (of cereal)' and $\operatorname{Consiv}(i) a^{66}$ 'she, who is the plenty of grain (from the sowing and used for the next sowing)' leave the sacral competences of Ops to no doubt. The August Opalia reflect the divinity's connection with agricultural fertility cults, for they comply with the sequence of celebrations of agrarian and vegetative character, which end the agricultural works with the after harvest ceremonies and the beginning of the autumnal sowing of cereals.

\begin{abstract}
Mensis September ${ }^{67}$
1 September: Iuno Regina; Iunoni Reginae eo die aedes dedicata est.

13 September: Minerva et Iuppiter; Iovis epulum; Minervae epulum ${ }^{68}$. 26 September: Venus Genetrix. Veneri Genetrici eo die aedis dedicata est.
\end{abstract}

\begin{abstract}
Mensis October
1 October: Iuno Sororia; Tigillum Sororium.

7 October: Iuno Curritis vel Quiritis; Iunoni Curriti eo die aedes dedicata est.

9 October: Venus Victrix (Capitolina); Veneri Victrici eo die aedis dedicata est.
\end{abstract}

It is probable that the festivals held in the honour of Juno under the epithet Sororia contain an ancient initiation rite for girls. This celebration took part near the place called by Romans Tigillum Sororium and hence the name noted in the fasti. This celebration was supposed to confirm the young Roman girls readiness for their roles as wives and mothers. Such theory finds support in the etymological study of Juno's epithet, for linguists see in the lexeme sororia the Indo-European root "sÁĕl 'to swell (in reference to the girls' breasts)' ${ }^{69}$. This festival must have been of sacral as well as of public character, which ritual indicated the girls' beginning of puberty and entering physical maturity ${ }^{70}$.

${ }^{65}$ Latin ops (sg.) 'power, force, help'; (pl.) 'fortune, riches'.

${ }^{66}$ A. WALde and J.B. Hofmann (Lateinisches..., vol. I, p. 265) agree that the epithet Consiva (-ia) is the ritual equivalent of Consus, the male partner of Ops; the goddess' epithet was constructed from this theonym. Linguists derive the name of the god Consus from the Latin verb condère 'to hold on to, to hide'. He was supposed to take care of the bringing of cereals from the fields and their placing in the siloses.

${ }^{67}$ Cf. footnote 16 .

${ }^{68}$ Epulum was an opulent feast organized for the gods. The mentioned festival was probably an enrichment to the annual celebration of the dedication of the temple of Juppiter, Juno and Minerva on the Capitolium erected at the end of the sixth century BC.

${ }^{69}$ G. RADKe, Die Götter..., p. 291. The Latin verb sororiare describes 'the swelling of breasts of young girls' (Festus, De verborum significatu, p. 396).

${ }^{70}$ N. BoËLs-JANSSEN, La vie religieuse des matrones dans la Rome archaïque, Rome 1993 [= ColEFR, 176], p. 42; H.H. Scullard, Festivals and Ceremonies of the Roman Republic, London 1981 [= AGRL], p. 190 . 


\section{Mensis November ${ }^{71}$}

13 November: Feronia; Feroniae eo die aedes dedicata est.

13 November: Fortuna Primigenia; Fortunae Primigeniae eo die aedes dedicata est.

Mensis December

13 December: Tellus et Ceres; Telluri et Cereri eo die aedes dedicata est.

19 December: Ops; Opalia.

21 December: Angerona; Divalia.

23 December: Acca Larentina vel Acca Larentia; Larentalia.

The December Opalia, another festival after the one in August in honour of Ops, belonged to a series of feasts that began the preparations for the new agrarian season. The intervention of the goddess was supposed to provide the Romans with the multiplication of the vital forces of grain sowed into the soil during autumnal sowing, as well as with a good harvest.

The significance of Angerona for the system of Roman beliefs is emphasized mainly by the date of her festival, which coincided with the winter solstice. In view of many researches, ancient religions assigned this time of the year a sacral value, as a time when the forces of darkness combated those of the light over the rule of the vital forces of the world. Such hypothesis may be supported by the suggestions of some linguists on the etymology of the deity's name which is supposed to

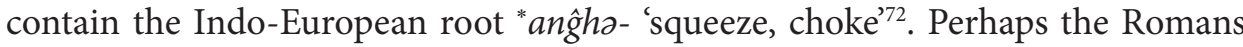
recognized in Angerona a divinity that 'choked' the light of the sun. Divalia was interpreted as a culmination of the moment of this struggle between light and darkness.

Acca Larentina vel Larentia belonged to those Roman deities of clearly chthonic nature, for during the festivals in her honour public offerings in honour of the dead were performed ${ }^{73}$. In the Roman calendar, such type of festivals appeared at the end of the old and the beginning of the new year and were aimed at protecting people from attacks from hostile forces towards living beings. Acca Larentia is the semantic equivalent of the description Mater Larum (Mother of Lares), also known as Mania. In honour of Mania and the Lares with the epithet Compitales which protected crossroads, the Romans held the festival termed Compitalia. In contrast to the Larentalia, a festival in honour of Acca Larentia, this one had a changeable date that appeared between the end of December and more often at the beginning of January. It is possible that the Larentalia and Compitalia may have been two versions of the same festival, although, according to literary sources, the Compitalia used to have a more dramatic course in ancient times, for the most important

\footnotetext{
${ }^{71} \mathrm{Cf}$. footnote 16.

${ }^{72}$ G. RADKE, Die Götter..., p. 64.

${ }^{73}$ Macrobius, Saturnalia, I, 10, 17.
} 
part of the festival were sacrifices ${ }^{74}$ of children in honour of Mania and the Lares, i.e. the spirits of the dead; such offering was intended to maintain the lives of the other members of the family ${ }^{75}$. In later times, the savage norm of performing human sacrifice was lifted. As a result, depictions resembling human beings were hung in front of the main entrance to the house $\mathrm{e}^{76}$ and on the crossroads ${ }^{77}$.

$$
* * *
$$

Based on the above-mentioned information about the sacral festivals in honour of the goddesses found in the fasti and literary sources, we may formulate the hypothesis in regard of the changes to which the cults of female Roman deities were subjected. Firstly, some of them lost their sacral significance, whereas their primary competences became forgotten; others expanded their religious influence and became important figures in the pantheon. For instance, those female numina gained more significance, whose sacral functions allowed the Roman community to fulfil its civilian duties or attribute sacral value to those activities that supported the security of Rome and its inhabitants in regard of the physical and spiritual spheres. This was due to the fact that pax deorum guaranteed the community's biological existence when religious acts were performed by its members. Furthermore, residents of Rome also took over the cults of conquered tribes and peoples, enriching and supplementing their own pantheon. The Romans consequently and efficiently established their historical politics, which enabled them to justify their territorial acquisitions but also facilitate the cultural domination over foreigners, i.e. non-Roman social and sacral communities. This way they developed an ideologically coherent religious system with complex ceremonies, which satisfied the most essential material and non-material needs of city residents.

In view of the discussion above, we may divide the many festivals dedicated to female Roman into groups of sacral sequences on the basis of the character of ritual conducts, which directly present the competences ascribed to the goddesses by the Roman sacral community:

1. Festivals in honour of agro-vegetative deities appear throughout the Roman sacral year, but dominate in the time of spring, the seasonal growth of cereal (January - feriae Sementivae, April - Fordicidia, Cerialia, Robigalia, Floralia, May - sacrum Deae Diae). The success of these protected the Roman community from poor harvest and famine.

\footnotetext{
${ }^{74}$ Researchers of religious studies define this sacrifice as pars pro toto, i.e. 'a part instead of the whole' (W. Burkert, Stwarzanie świętości. Ślady biologii we wczesnych wierzeniach religijnych, trans. L. Trzcionkowski, Kraków 2006, p. 77).

${ }^{75}$ Macrobius, Saturnalia, I, 7, 34-35.

${ }^{76}$ Macrobius, Saturnalia, I, 7, 34-35.

${ }^{77}$ Festus, De verborum significatu, p. 344.
} 
2. Festivals in honour of the goddesses who were patronesses of women's fertility and the health of little children were performed by Roman woman almost throughout the whole year (January - Carmentalia, March - Matronalia, April - Veneralia, sacrum Forunae Virili, May - sacrum Deae Bonae ${ }^{78}$, June - ludi fabarici, Matralia, sacrum Fortis Fortunae, July - Nonae Caprotinae, August - sacrum Dianae, October - Tigillum Sororium, December - sacrum Bonae Deae). These were aimed at protecting the community from the loss of control over its growth.

3. Festivals at the turn of the sacral year dedicated to goddesses appear in March, with which the Romans initiated the religious year (March - the extinguishing of the fire in the Vesta temple, March - sacrum Annae Perennae) as well as at the turn of December and January (December - Divalia, Larentalia, December or January - Compitalia), and also at the beginning of the pastoral year (April - Parilia). Often, these festivals were of purifying and apotropaic character; they isolated the Roman community from chthonic forces that threatened human beings.

4. A characteristic feature of some agrarian, female and turn-of-the-year festivals was the disruption of accepted norms of conduct: the abuse of wine, erotic freedom, nudity of the female participants of the festival, sexual acts, including groups sex obscene gestures, vulgar lore (March - sacrum Annae Perennae, April - Floralia, June - sacrum Fortis Fortunae). These actions were aimed at enforcing the life force accumulated on earth, as well as the birth forces attributed to women by nature, so that harvest and human fertility would guarantee Rome's security and biological continuity ${ }^{79}$.

\footnotetext{
${ }^{78}$ Bona Dea was a deity whose two festivities were intended only for women. The December festival had the Roman women, both unmarried and married, gather in the house of one of the Roman officials. The basic requirement for this nocturnal festival, which was conducted pro populo Romano, was the expulsion of all men and male animals as well as the hiding of objects with phallic connotations. The goddess' protection was supposed to favour the baring of many children by the Roman women; cf. Cicero, De Haruspicum Responsis, 37; Plutarchus, Caesar 9-10, [in:] Plutarch's Lives. In Eleven Volumes, vol. I, trans. B. Perrin, London 1959. Cf. H.H.J. Brouwer, Bona Dea. The Sources and a Description of the Cult, Leiden 1989 [= EPROLR, 110], p. 398: as a fertility goddess and through the female, representative, part of the population she guarded the community.

${ }^{79}$ In ancient religions, harvest was connected with female fertility, hence the sowing of seeds was identified with the sexual act (H. Le Bonniec, Le culte de Cérès à Rome. Des origines à la fin de la République, Paris 1958, p. 128; M. ElIAde, Historia wierzeń i idei religijnych, vol. I, Od epoki kamiennej do misteriów eleuzyńskich, trans. S. ToKARSKI, Warszawa 1997, p. 29).
} 


\section{Bibliography}

\section{Primary Sources}

Acta Fratrum Arvalium quae supersunt, ed. W. Henzen, Berolini 1874.

Albii Tibulli Aliorumque Carmina, ed. G. Luck, Stutgardiae 1988 [= Bibliotheca scriptorum Graecorum et Romanorum Teubneriana].

Ambrosii Theodosii Macrobii Saturnalia, vol. I, ed. I. WiLlis, Lipsiae 1963 [= Bibliotheca scriptorum Graecorum et Romanorum Teubneriana].

Auli Gellii Noctium Atticarum libri XX, vol. I-II, rec. C. Hosıus, Stutgardiae 1981 [= Bibliotheca scriptorum Graecorum et Romanorum Teubneriana].

Cicero, De Haruspicum Responsis, [in:] Cicero, The Speeches, trans. N.H. WAtts, London 1961 [= Loeb Classical Library, 158], p. 312-401.

Cicero, De Legibus, [in:] Cicero, De Re Publica. De Legibus, trans. C.W. Keyes, London 1969 [= Loeb Classical Library, 213], p. 289-520.

Cicero, De Re Publica, [in:] Cicero, De Re Publica. De Legibus, trans. C.W. Keyes, London 1969 [= Loeb Classical Library, 213], p. 2-288.

Cicero, The Verrine Orations, vol. I-II, trans. L.H.G. Greenwood, London 1959-1960 [= Loeb Classical Library, 221].

Columella, On Agriculture, vol. III, Books 10-12. On Trees, trans. E.S. Forster, E.H. Heffner, London 1955 [= Loeb Classical Library, 408].

Corpus Inscriptionum Latinarum. Editio altera, vol. I, Berlin 1903.

Degrassi A., Fasti anni Numani et Iuliani, Rome 1963 [= Inscriptiones Italiae, 13.2].

Festus, De verborum significatu, [in:] Glossaria Latina, vol. IV, Placidus, Festus, ed. J.W. PIrIE, W.-M. LindSAY, Hildesheim 1965.

L. Annaei Senecae Ad Lucilium Epistulae Morales, vol. I-II, ed. L.D. Reynolds, Oxonii 1965 [= Scriptorum Classicorum Bibliotheca Oxoniensis].

M. Terentius Varro, Antiquitates Rerum Divinarum, vol. I, Die Fragmente, vol. II, Kommentar, ed. B. Cardauns, Wiesbaden 1976.

Nonii Marcelli De conpendiosa doctrina libros XX, vol. I, LL. I-III, ed. W.M. LINDSAY, Lipsiae 1903.

Ovid's Fasti, trans. J.G. Frazer, London 1959 [= Loeb Classical Library, 253].

Plutarch's Lives. In Eleven Volumes, vol. I, trans. B. PERrin, London 1959.

Servii Grammatici qui feruntur in Vergilii Carmina Commentarii, ed. G. Thilo, H. Hagen, vol. I, Aeneidos librorum I-V Commentarii, ed. G. ThILo, Hildesheim 1961.

Valeri Maximi Factorum et Dictorum Memorabilium libri novem, ed. C. HALM, Lipsiae 1865.

VArro, On the Latin Language, vol. I, Books V-VII, vol. II, Books VIII-X, Fragments, trans. R.G. KenT, London 1938 [= Loeb Classical Library, 333-334].

\section{Dictionaries}

CARnoy A., Dictionnaire étymologique de la mythologie gréco-romaine, Louvain 1957.

Walde A., Hofmann J.B., Lateinisches etymologisches Wörterbuch, vol. I, Heidelberg 1938 [= Indogermanische Bibliothek, 1]. 


\section{Secondary Literature}

Benoist S., La Fête à Rome au premier siècle de l'Empire. Recherches sur l'univers festif sous les règnes d'Auguste et des Julio-Claudiens, Bruxelles 1999.

BoËLs-JANSSEN N., La vie religieuse des matrones dans la Rome archä̈que, Rome 1993 [= Collection de l'École française de Rome, 176].

Bonniec Le H., Le culte de Cérès à Rome. Des origines à la fin de la République, Paris 1958.

Brouwer H.H.J., Bona Dea. The Sources and a Description of the Cult, Leiden 1989 [= Études préliminaires aux religions orientales dans l'empire romain, 110].

Burkert W., Stwarzanie świętości. Ślady biologii we wczesnych wierzeniach religijnych, trans. L. Trzcionkowski, Kraków 2006.

DumézIL G., Carna, "Revue des études latines" 38, 1960, p. 87-100.

Eliade M., Historia wierzeń i idei religijnych, vol. I, Od epoki kamiennej do misteriów eleuzyńskich, trans. S. TOKARSKI, Warszawa 1997.

Frazer J.G., Złota gałąź, trans. H. KRzeCZKowski, Warszawa 1996.

Gillmeister A., Musia£ D., W cieniu Kapitolu. Religia starożytnych Rzymian, Kraków 2012.

JaCzynowska M., Religie świata rzymskiego, Warszawa 1987.

KaCzor I., Sakralizacja czasu w rzymskim systemie wierzeń, [in:] Kategorie i funkcje czasu w ujęciu starożytnych, ed. J. Czerwińska, I. KaCzor, M. KoźLuk, A. Lenartowicz, J. RybowsKa, Łódź 2009, p. 223-239.

Radke G., Beobachtungen zum Namen des Festes der Cerialia, [in:] Hommages à Henri Le Bonniec. Res Sacrae, ed. D. Porte, J.-P. Néraudau, Bruxelles 1988 [= Collection Latomus, 201], p. 364-372.

Radke G., Die Götter Altitaliens, Münster 1965.

RiEs J., Héritage indo-européen et religion romaine. À propos de La religion romaine archaïque de Georges Dumézil, "Revue Théologique de Louvain" 7, 1976, p. 476-489.

RÜPкE J., Roman Religion-Religions of Rome, [in:] A Companion to Roman Religion, ed. J. RüPKE, Malden 2007, p. 1-9 [= Blackwell Companions to the Ancient World].

SabBatucci D., La religione di Roma antica. Dal calendario festivo all'ordine cosmico, Milano 1988.

Scheid J., Le délit religieux dans la Rome tardo-républicaine, "Publications de l'École Française de Rome" 48, 1981, p. 117-171.

Scheid J., La religion des Romains, Paris 1998 [= Cursus. Histoire de l’Antiquité].

SCHeId J., La religione a Roma, trans. M.N. Pierini, Bari 1983.

Schilling R., La relation Venus-Venia, "Latomus" 21, 1962, p. 3-7.

Schilling R., La religion romaine de Vénus depuis les origines jusqu'au temps d'Auguste, Paris 1954.

Schultz C.E., Women's Religious Activity in the Roman Republic, Chapel Hill-London 2006 [= Studies in the History of Greece and Rome].

Scullard H.H., Festivals and Ceremonies of the Roman Republic, London 1981 [= Aspects of Greek and Roman Life].

Spaeth B.S., The Roman Goddess Ceres, Austin 1996.

Staples A., From Good Goddess to Vestal Virgins. Sex and Category in Roman Religion, London 1998.

TAKÁcs S.A., Vestal Virgins, Sibyls and Matrons. Women in Roman Religion, Austin-Chesham 2008.

Wright R., Vesta. A Study on the Origin of a Goddess and Her Cultus, Washington 1995. 
Abstract. Ancient Romans' sacral community established a cohesive and complex religious system. Its reflection was a multi-figural pantheon of gods with a variety of sacral functions that were supposed to meet the most essential material and non-material needs of the members of this religious community. This article focuses on those needs of great importance to the whole community of Rome which were met by the female figures of the Roman pantheon.

Keywords: Roman female deities, Roman religious cults, Roman pantheon of gods

Idaliana Kaczor

Uniwersytet Łódzki

Wydział Filologiczny

Katedra Filologii Klasycznej

ul. Pomorska 171/173

90-236 Łódź, Polska/Poland

idaliana.kaczor@uni.lodz.pl 